\title{
Financial Feasibility and Competitiveness Levels of Soybean Varieties in Rice-Based Cropping System of Indonesia
}

\author{
Ruly Krisdiana, Nila Prasetiaswati, Imam Sutrisno, Fachrur Rozi, Arief Harsono and Made Jana Mejaya *D \\ Indonesian Legume and Tuber Crops Research Institute (ILETRI), Malang 65101, Indonesia; \\ rulykrisdiana@pertanian.go.id (R.K.); nilaprasetiaswati@pertanian.go.id (N.P.); \\ imamsutrisno@pertanian.go.id (I.S.); fachrurrozi@pertanian.go.id (F.R.); ariefharsono@pertanian.go.id (A.H.) \\ * Correspondence: janamejaya@pertanian.go.id
}

check for updates

Citation: Krisdiana, R.; Prasetiaswati, N.; Sutrisno, I.; Rozi, F. Harsono, A.; Mejaya, M.J. Financial Feasibility and Competitiveness Levels of Soybean Varieties in Rice-Based Cropping System of Indonesia. Sustainability 2021, 13, 8334. https://doi.org/ $10.3390 /$ su13158334

Academic Editors: Alexandra Jacquelyn Burgess and Sean Clark

Received: 14 June 2021

Accepted: 20 July 2021

Published: 26 July 2021

Publisher's Note: MDPI stays neutral with regard to jurisdictional claims in published maps and institutional affiliations.

Copyright: (c) 2021 by the authors. Licensee MDPI, Basel, Switzerland. This article is an open access article distributed under the terms and conditions of the Creative Commons Attribution (CC BY) license (https:// creativecommons.org/licenses/by/ $4.0 /)$.

\begin{abstract}
This research was conducted to determine the financial feasibility of growing soybean varieties and their competitiveness in the rice-based cropping system of Indonesia. The research was conducted at two locations in 2020. The results showed that the use of improved varieties of soybean yielded $2.24 \mathrm{t} / \mathrm{ha}$ and $2.09 \mathrm{t} / \mathrm{ha}$, which was higher than using local (non-improved) varieties. The use of improved varieties was financially feasible with Revenue Cost (R/C) ratios of 1.88-1.98 and Benefit Cost (B/C) ratios of 0.88-0.98. The competitiveness of soybeans in Mojokerto and Pasuruan was lower compared to maize and mungbean. Soybean could compete with competing crops if the productivity and price were higher than the current conditions. To be able to compete with maize, the soybean productivity should be 5.14-5.22 $\mathrm{t} /$ ha if the current soybean price per $\mathrm{kg}$ is IDR 7200 (about US \$ 0.51). To compete with mungbean, the soybean productivity should reach $3.05 \mathrm{t} / \mathrm{ha}$ with the current price per kg of IDR 7200 (about US \$ 0.51). When measured by the price level, to be able to compete with maize, the soybean selling price per kg should be IDR 14,428-IDR 14,893 (about USD 1.06) with a productivity level of $2.24 \mathrm{t} / \mathrm{ha}$.
\end{abstract}

Keywords: competitiveness level; cropping pattern; financial feasibility; soybean; Indonesia

\section{Introduction}

Soybean is the main ingredient in tofu and tempeh, which is one of the favorite food ingredients of Indonesian people. The demand for soybean continues to increase. Currently, soybean production in Indonesia is only able to meet $30-40 \%$ of the national consumption for 2.6 million tons per year [1]. The demand for soybean continues to increase as a result of the increasing population and the increasing variety of processed products and industrial raw materials. Tempeh and tofu dominate the use of soybeans as a source of protein for low-income families. The other uses of soybeans are for soy milk, soy sauce, bean sprouts, tauco, flour, and other processed products. Tempeh is consumed by frying because it is easy and tastes delicious.

In 2014, the harvested area for soybeans was 615,685 ha and increased to 680,373 ha in 2018. Similarly, total production increased from 954,997 tonnes in 2014 to 982,598 tonnes in 2018. However, the productivity decreased from $1.55 \mathrm{t} /$ ha in 2014 to $1.44 \mathrm{t} / \mathrm{ha}$ in 2018 [2]. Increasing the production and productivity of soybean is becoming necessary to meet market demands. To increase the productivity of soybean, the adoption of recommended technology by farmers is needed. One of the technology components is the adoption of improved varieties resulting from a breeding program. Improved varieties have one or more special advantages such as high yield potential, pest and disease resistance, tolerance to environmental stress, product quality, or other characteristics. The use of improved varieties suitable for the local environment is one of the important requirements for successful farming. High-yielding varieties are technology that farmers are interested in and are easily adopted. Soybean production in Indonesia is carried out on optimal 
land, namely rice fields and dry land or rainfed lands that are not constrained by chemical, physical, or environmental factors.

Indonesia's rice field area in 2015 reached 8,087,393 hectares [2]. Based on data from the Ministry of Agriculture, this number consists of 4.78 million ha of irrigated rice fields and 3.4 million ha of non-irrigated rice fields. These lands have potential for soybean development. Soybean grown on optimal land is more productive and more efficient than dry land. This can be due to optimal soybean growth and does not require inputs (soil amendments) other than fertilization which can be carried out according to recommendations for optimal land. The East Java province is the largest soybean area in Indonesia. The average land area owned by each farmer for food crops, especially soybeans, is less than 0.50 ha. In general, the cropping patterns are rice-rice-soybean, rice-rice-maize, rice-maize-mungbean, and rice-maize-maize cropping patterns. During harvest time, the farmers sell the soybean grains to local markets or to the local buyers who collect the soybean grains from the farmers' houses.

Increasing soybean production in Indonesia to achieve self-sufficiency faces the problem of insufficient harvest area and low crop productivity. For the expansion of the harvested area in Indonesia, there is an optimal area of land, including rice fields. In order for soybeans to develop in these lands, location-specific cultivation technologies that are productive, efficient, economically feasible, and highly competitive are needed. To increase the soybean harvested area, agricultural development is faced with an area of fertile (optimal) land that is decreasing due to the conversion of its functions to other sectors by $1 \%$ per year [1]. Efforts to increase soybean production carried out by the government with the goal of achieving self-sufficiency face three main problems: the harvest area for soybeans is not large enough, productivity is still low, and the competitiveness of soybean commodities is still inferior to other food crops such as peanuts and maize. Therefore, one of the efforts that can be made to increase national soybean production in order to achieve self-sufficiency is to increase the productivity of soybeans, which currently has only reached $1.50 \mathrm{t} / \mathrm{ha}$ to around $3.0 \mathrm{t} / \mathrm{ha}$.

Soybean cultivation technology is needed in optimal land that can increase productivity, is economically feasible, and has high competitiveness. Technology adoption is a dynamic process that changes over time. Therefore, the technology to be developed needs to be evaluated for its feasibility first at the farmer level. Financial feasibility analysis is an important aspect in assessing product development, because it can determine the feasibility of a business based on the usefulness and benefits it generates. New technology is not only technically feasible for agronomics, but it is also expected to have a direct impact on the acceleration of technology adoption, increase in crop production, and farmers' income [3,4]. Adaptive and appropriate technology has four characteristics, namely being technically usable, economically beneficial, socially acceptable, and environmentally friendly [5]. The characteristics of innovation will determine whether or not farmers adopt an innovation, namely from the nature of relative advantages, suitability, complexity, ease of trial, and if it can be distinguished from the older technology [6]. Improved varieties are one component of technological innovation that plays an important role in increasing production. Among the technological innovations in soybean cultivation, improved varieties are the most capable technology component for increasing productivity per unit area. The use of improved varieties together with other components of cultivation technology will provide yield increase in order to support national soybean production as well as increase the welfare of farmers. The Indonesian Legume and Tuber Crops Research Institute (ILETRI) has developed several improved soybean varieties. The ILETRI is an institution that conducts research on various legumes and tuber crops. This institution is under the Indonesian Center for Food Crops Research and Development (ICFORD), Indonesian Agency for Agricultural Research and Development (IAARD), Ministry of Agriculture of the Republic of Indonesia. ILETRI has released more than 25 improved varieties with average grain yields of 3 tonnes/ha. More than 3 tonnes of the Breeder Seeds class of these soybean 
varieties are distributed annually to seed growers throughout the country to produce the Extension Seeds class for farmers.

In carrying out soybean farming, farmers usually use family labor and labor outside the family, depending on their activities. For land preparation activities (cleaning straw, drainage channels), planting, harvesting, and post-harvesting are usually carried out by workers outside the family. Meanwhile, the activities of fertilizing, spraying, and weeding are carried out by family workers. Therefore, the number of family members affects the activities of a farm. Family members who are involved in farming activities usually also have other jobs (besides agriculture) because the activities carried out in the agricultural sector only require a short amount of time.

The objective of this study was to determine the financial feasibility of improved soybean varieties and their competitiveness against alternative crops in rice-based cropping systems of Indonesia.

\section{Materials and Methods}

\subsection{Study Area}

The research was conducted in soybean production centers in Mojokerto and Pasuruan Regencies, East Java Province, Indonesia, where the improved soybean varieties from ILETRI were planted. In Mojokerto Regency, the research was carried out in three villages of the Bangsal District (Sidomulyo, Gayam, and Wunut), while in Pasuruan Regency, it was carried out in the Tunggulwulung Village of the Pandaan District. The Bangsal District of the Mojokerto Regency is located at the coordinates of $7^{\circ} 49^{\prime} 71.4^{\prime \prime}$ South Latitude and $112^{\circ} 48^{\prime} 21.4^{\prime \prime}$ East Longitude, while the Pandaan District of the Pasuruan Regency is located at the coordinates of $7^{\circ} 65^{\prime} 39.0^{\prime \prime}$ South Latitude and $112^{\circ} 69^{\prime} 35.3^{\prime \prime}$ East Longitude. The distance between Mojokerto and Pasuruan is $64.80 \mathrm{~km}$. The two areas were chosen in this study because they are one of the centers of Indonesian soybean production and carry out the cultivation of high-yielding soybean varieties from ILETRI. The land area for food crops, especially various legumes (soybeans, peanuts, mungbeans), is usually small. The average land area in the study area is $0.22 \mathrm{ha}$. All areas of soybean production centers in other regions in Indonesia are not much different from Mojokerto and Pasuruan.

The research was conducted in September-November 2020, involving 84 cooperator farmers and 26 non-cooperator farmers, so that the total sample was 110 farmers. The data were taken on the dry season II soybean cropping or after the first soybean planting in the rice-soybean-soybean rotation, as well as on non-soybean competitor crops.

\subsection{Data Collection}

The data were collected by interviewing the farmers using a structured questionnaire. The data taken were related to the input-output or production practices for soybean farming which includes soil planting preparation, planting, fertilizing, spraying pesticides and herbicides, weeding, harvesting, post-harvest activities (transport and thresher), as well as labor requirements of soybean and plant farming competitors and their respective prices. Cooperator farmers are farmers who grow soybeans using labeled improved variety seeds but their cultivation technology (planting methods, use of fertilizers, pesticides, herbicides, harvest methods, and post-harvest) is still what farmers usually apply. Non-cooperator farmers are farmers who do not use derivative improved variety seeds (which have been planted repeatedly) and their cultivation techniques are based on standard local production practices. Interviews were conducted twice, first during land preparation activities and weeding and second during harvest and post-harvest activities.

\subsection{Data Analysis}

The analysis used in this research is descriptive analysis to determine the financial feasibility of soybean farming and the competitiveness of soybean against its competitors in a rice-based cropping system. Descriptive analysis describes the state of the soybean commodity in selected areas on optimal land. 
Financial feasibility analysis is an analysis to show the feasibility of a farm by using input-output or production facilities as well as its labor requirements. This analysis is a measure to determine the feasibility of a farm and written as follows [7]:

Cost of production facilities $=\Sigma \mathrm{Hxi} \times \mathrm{Xi}$

Labor costs $=\Sigma$ Htki $\times$ Tki

Farming costs $=(1)+(2)$

Revenue $=\mathrm{Hq} \times \mathrm{Q}$

Profit $=(4)-(3)=(5)$

Benefits Cost $(\mathrm{B} / \mathrm{C})$ ratio $=(5) /(3)$

Revenue Cost $(\mathrm{R} / \mathrm{C})$ ratio $=(4) /(3)$

where $\mathrm{B} / \mathrm{C}$ ratio $>0$ : the farming is profitable and feasible to be cultivated

$\mathrm{B} / \mathrm{C}$ ratio $<0$ : farming is not profitable and not feasible to be cultivated

$\mathrm{R} / \mathrm{C}$ ratio $>1$ : farming is profitable and feasible to be cultivated

$\mathrm{R} / \mathrm{C}$ ratio $<1$ : farming is not profitable and not feasible to be cultivated

To determine the increase in income or profits from the existence of innovative technology, the Marginal Benefit Cost Ratio (MBCR) [8] employs the formula:

$$
M B C R=\frac{I_{t 1}-I_{t 0}}{T C_{t 1}-T C_{t 0}}
$$

where:

$\mathrm{I}_{\mathrm{t} 1}=$ new technology revenue;

$\mathrm{I}_{\mathrm{t} 0}=$ previous technology revenue;

$\mathrm{TC}_{\mathrm{t} 1}=$ total cost of new technology;

$\mathrm{TC}_{\mathrm{t} 0}=$ total cost of previous technology.

The following formulas are used to calculate the production break-even point (BEP production) and the price break-even point (BEP price):

$$
\begin{aligned}
& \mathrm{BEP} \text { production }=\text { total } \mathrm{cost} / \mathrm{price} \text { of production } \\
& \mathrm{BEP} \text { price }=\text { total cost } / \text { production }
\end{aligned}
$$

Competitiveness analysis:

The competitiveness between commodities in a mathematical model can be formulated as follows $[9,10]$ :

Competitive rate of return:

$$
Y_{k}^{1}=\left[\left\{\left(\frac{N R_{j}^{0}}{N R_{k}^{0}}\right) T C_{k}^{0}\right\}+N R_{j}^{0}\right] / P_{k}^{0}
$$

where:

$Y_{k}^{1}=$ level of soybean yield to compete with plant $\mathrm{j}(\mathrm{kg} / \mathrm{ha})$;

$T C_{k}^{0}=$ the original total variable cost of soybeans (IDR/ha);

$N R_{j}^{0}=$ net plant revenue $\mathrm{j}(\mathrm{IDR} / \mathrm{ha})$;

$P_{k}^{0}=$ original soybean price (IDR $\left./ \mathrm{kg}\right)$;

$N R_{k}^{0}=$ original net revenue of soybeans (IDR/ha).

Competitive output price level:

$$
P_{k}^{1}=\left(T C_{k}^{0}+N R_{j}^{0}\right) / Y_{k}^{0}
$$

where $P_{k}^{1}=$ the competitive price of soybean against plant $\mathrm{j}$ (IDR $/ \mathrm{kg}$ ). 


\section{Results}

\subsection{Characteristic of Soybean Farmers}

The characteristics of soybean farmers in Mojokerto and Pasuruan are almost the same in terms of age, education level, experience in soybean farming, number of family members and the area of cultivated rice fields they own. The average age in both regions is 50 years and over, with the highest levels of education at the elementary/primary school and junior high school levels with a percentage of more than $50 \%$ and $30 \%$, respectively. Senior high school education level in Mojokerto (15.9\%) was greater than in Pasuruan $(4.6 \%)$. The undergraduate level in Mojokerto was $2.3 \%$ and in Pasuruan, there were no farmers with a bachelor's level of education. Regarding soybean cultivation, the average farmer has 18 years of experience in Mojokerto and 17 years in Pasuruan. The average number of family members in both regions is three people and the average land size is 0.2 ha of paddy field (Table 1).

Table 1. Characteristics of soybean farmers in the Mojokerto and Pasuruan Regencies (2020).

\begin{tabular}{lcc}
\hline \multicolumn{1}{c}{ Description } & Mojokerto & Number of Farmers (\%) \\
& Pasuruan \\
\hline Age (years) & 53.38 (range 47-64) & 54 (range 37-60) \\
Education level: & & 59.0 \\
$\quad$ Elementary School & 50.0 & 36.4 \\
$\quad$ Junior High School & 31.8 & 4.6 \\
$\quad$ Senior High School & 15.9 & 0 \\
$\quad$ Undergraduate & 2.3 & 17 (range 5-25) \\
Farming experience (years) & 18.63 (range 4-30) & 3.75 (range 2-6) \\
Number of family members (person) & 3.88 (range 2-5) & 0.217 (range 0.19-0.50) \\
Size of cultivated land area (ha) & 0.22 (range 0.04-1.4) & \\
\hline
\end{tabular}

There are various reasons for farmers to keep farming soybeans, including the most common factors: habit, easy maintenance, water availability, land suitability, low costs, and easy marketing $(18.46 \%, 16.54 \%, 15.38 \%, 12.31 \%, 12.31 \%$, and $7.69 \%$, respectively). Soybean plants in the study area play a very important role for farmer households, namely as a source of income (95\%) apart from rice, and other roles (5\%) such as being a land cover crop, meeting household needs, and providing funds to cover school fees or purchase land/rice fields, and for savings (Table 2).

Table 2. Reasons and roles of soybean crops for farmers in Mojokerto and Pasuruan (2020).

\begin{tabular}{cccc}
\hline Reasons of Soybean Farming (\%) & \multicolumn{2}{c}{ Roles of Soybean Crops for Farmers (\%) } \\
\hline Habit & 18.46 & Source of revenue & 94.9 \\
Easy maintenance & 16.54 & School fees & 1.5 \\
Water availability & 15.38 & As land cover crop & 1.2 \\
Land suitability & 12.31 & To reserve household needs & 1.2 \\
Low costs of farming & 12.31 & Purchase land/rice fields & 0.8 \\
Easy marketing & 7.69 & For savings & 0.4 \\
Availability of seeds & 6.54 & & \\
High revenue & 5.38 & \\
High selling price & 4.62 & \\
Free seed program & 0.38 & \\
\hline Total & 100 & \\
\hline
\end{tabular}

\subsection{The Soybean Varieties and Cropping Pattern}

Soybean farmers in Mojokerto and Pasuruan used improved varieties from ILETRI as technology components for soybean farming in both regions. Various high yielding varieties of soybeans were used with characteristics such as being tolerant to pod sucking pests (Derap), shade tolerant (Dena), acid soil tolerant (Demas), drought tolerant (Dering), 
shattering pod tolerant (Detap), high isoflavone level (Devon), early maturity (Dega), and large seed size (Anjasmoro) (Table 3).

Table 3. Soybean improved varieties grown by farmers in Mojokerto and Pasuruan (2020).

\begin{tabular}{ccc}
\hline \multirow{2}{*}{ Soybean Varieties Grown } & \multicolumn{2}{c}{ Number of Farmers (\%) } \\
\cline { 2 - 3 } & Mojokerto & Pasuruan \\
\hline Cooperator farmers: & 30.0 & \\
Derap & 5.9 & \\
Devon 1 & 1.9 & \\
Devon 2 & 11.3 & \\
Dena 1 & 1.9 & \\
Dena 2 & 15.0 & \\
Dega 1 & 1.9 & \\
Demas & 5.6 & \\
Dering & 20.4 & \\
Detap 1 & 6.0 & \\
Anjasmoro & & \\
Non-cooperator farmers: & 12.5 & \\
Wilis (derivatives seeds) & 75.0 & \\
Devon 1 (derivatives seeds) & 12.5 & \\
Kretek (local variety) & & \\
\hline
\end{tabular}

Cooperator farmers in Mojokerto all planted improved varieties as mentioned above with the highest percentage being Derap, Detap 1, Dega 1, and Dena 1, with $30 \%, 20.7 \%$, $15 \%$, and $11.3 \%$ respectively. Whereas for Pasuruan all of them used the improved variety Detap $1(100 \%)$. Non-cooperator farmers are farmers who plant soybeans outside of ILETRI activities even though they also use improved varieties but the derivatives seeds (the seeds of the varieties that are planted repeatedly from the previous harvested areas without applying a proverly seed production procedures). These derivative varieties were Wilis, Devon 1, and Kretek which popular in the areas.

In Mojokerto the most widely used varieties are Devon 1 with a percentage of $75 \%$, and others Wilis and Kretek with $12.5 \%$ each. Meanwhile in Pasuruan all of them use derived Wilis varieties $(100 \%)$. Most of the farmers in Mojokerto (74\%) use rice-rice-soybean, and the rest $(26 \%)$ rice-paddy-maize rotation. In Pasuruan, the cropping patterns are more diverse, and the most consecutive are rice-rice-soybean, rice-rice-maize, rice-maizemungbean, and rice-maize-maize cropping patterns, each with $90 \%, 6.46 \%, 3.14 \%$, and $0.37 \%$, respectively (Table 4 ).

Table 4. Soybean cropping patterns in Mojokerto and Pasuruan Regencies (2020).

\begin{tabular}{ccc}
\hline Regencies & Cropping Patterns & Percentage (\%) \\
\hline Mojokerto & rice-rice-soybean & 74.00 \\
& rice-rice-maize & 26.00 \\
Pasuruan & rice-rice-soybean & 90.04 \\
& rice-rice-maize & 6.46 \\
& rice-maize-maize & 0.37 \\
& rice-maize-mungbean & 3.14 \\
\hline
\end{tabular}

\subsection{Farming Analysis and Level of Financial Feasibility}

The release of improved varieties is an effort to increase productivity, which ultimately has an impact on increasing farmers' income and welfare. The study was conducted 202 to determine the financial viability of soybean farming using improved varieties. In this study, the analysis of soybean farming was divided into cooperator and non-cooperator farmers. Cooperator farmers are farmers who plant soybeans using improved varieties of seeds from ILETRI but the cultivation technology (planting methods use of fertilizers, 
pesticides, herbicides, harvesting methods, and post-harvest) referred to as traditional farmers practices. While non-cooperator farmers do not use labeled improved variety seeds but derivative improved varieties (improved varieties that have been planted repeatedly) and also follow traditional farming practices. This condition indicates that farmers have actually used improved quality seeds even though some farmers only use improved derivatives. This may be due to the influence of farmers who are not old and still classified as productive age (53-54 years old on average), thus adopting technological innovations. The age of the farmer also influences the adoption of a technological innovation. Farmers of productive age will be more active in adopting technological innovations than older farmers. In the research area, the farmers were in productive age (average age 53-54 years) and they adopted the technological innovations.

In this study, the financial analysis of soybean farming was calculated based on the real costs incurred. The wages of family labor are not taken into account in this analysis. The results of the analysis showed that the cost of farming using improved varieties in Mojokerto was IDR $8,584,172$ (23.11\% cost of production facilities, $76.89 \%$ of labor costs) and IDR 7,391,652 in Pasuruan (30.56\% cost of production facilities and $69.44 \%$ cost of labor) (Table 5).

Table 5. Cost of production facilities per ha of soybean farming in Mojokerto and Pasuruan Regencies (2020).

\begin{tabular}{ccccc}
\hline \multicolumn{2}{c}{ Cooperator Farmers } & \multicolumn{2}{c}{ Non-Cooperator Farmers } \\
\hline $\begin{array}{c}\text { Soybean Production Input } \\
\text { Facilities }\end{array}$ & $\begin{array}{c}\text { Mojokerto } \\
\text { (IDR/ha) }\end{array}$ & $\begin{array}{c}\text { Pasuruan } \\
\text { (IDR/ha) }\end{array}$ & Mojokerto (IDR/ha) & $\begin{array}{c}\text { Pasuruan } \\
\text { (IDR/ha) }\end{array}$ \\
\hline Seeds (kg) & 889,820 & 810,556 & 857,856 & 642,375 \\
Fertilizer (kg): & 293,768 & 474,806 & 341,615 & 85,650 \\
Urea, SP36, Phonska & 154,231 & 349,025 & 24,140 & 21,412 \\
Organic fertilizer, gandasil D/B & 428,536 & 428,375 & 482,090 & 597,996 \\
Pesticide & 217,497 & 196,838 & 93,010 & 239,820 \\
Herbicide & $1,983,952$ & $2,259,600$ & $1,798,711$ & $1,587,253$ \\
\hline Total & & &
\end{tabular}

From the total cost of soybean farming with the use of technology, most is absorbed by labor costs. The large value of farming costs is due to inefficient expenditures on labor costs which absorb up to $70 \%$ of the total farming costs, while input costs (seeds, fertilizers, pesticides, herbicides) are 30\%. The largest labor costs are for planting and harvesting activities (Table 6).

Table 6. Labor cost of soybean farming per ha in Mojokerto and Pasuruan Regencies (2020).

\begin{tabular}{ccccc}
\hline & Cooperator Farmers & & \multicolumn{2}{c}{ Non-Cooperator Farmers } \\
\hline Labor Used Activities & $\begin{array}{c}\text { Mojokerto } \\
\text { (IDR/ha) }\end{array}$ & $\begin{array}{c}\text { Pasuruan } \\
\text { (IDR/ha) }\end{array}$ & Mojokerto (IDR/ha) & $\begin{array}{c}\text { Pasuruan } \\
\text { (IDR/ha) }\end{array}$ \\
\hline Land preparation & $1,585,765$ & $1,229,731$ & 829,811 & 535,312 \\
Seed planting & $1,898,400$ & $1,532,375$ & 930,100 & $1,348,987$ \\
Fertilizer application * & 289,067 & 345,956 & 213,000 & 171,300 \\
Pesticide application * $_{\text {Herbicide application * }}$ & 640,154 & 621,956 & 433,100 & 685,200 \\
Weeding * & 298,527 & 188,788 & 105,500 & 85,650 \\
Harvesting & 210,758 & 191,663 & 337,250 & $1,391,200$ \\
Post-harvest & $1,267,484$ & $1,296,619$ & $1,214,100$ & $1,056,350$ \\
\hline Total ** & $1,848,571$ & $1,073,327$ & 963,569 & $4,332,461$ \\
\hline
\end{tabular}

* Using family labour; ** Real cost. 
With the use of improved soybean varieties, the yields obtained by cooperator farmers were 27\% and 22\% higher than non-cooperator farmers in Mojokerto and Pasuruan, respectively. Whereas for cooperator farmers the average yield reached $2240 \mathrm{~kg} / \mathrm{ha}$, and $2090 \mathrm{~kg} / \mathrm{ha}$, and for non-cooperator farmers $1766 \mathrm{~kg} / \mathrm{ha}$, and $1720 \mathrm{~kg} / \mathrm{ha}$ respectively for Mojokerto and Pasuruan (Table 7). This production is still lower than the potential yield of $3.5 \mathrm{t} /$ ha produced by ILETRI. The yield potential in the field is influenced by the interaction between genetic factors and the management of environmental conditions. If the management of the growing environment is not carried out properly, the high yield potential of these improved varieties cannot be achieved.

Table 7. Financial analysis of soybean farming per ha in Mojokerto and Pasuruan, 2020.

\begin{tabular}{|c|c|c|c|c|}
\hline \multicolumn{3}{|c|}{ Cooperator Farmers } & \multicolumn{2}{|c|}{ Non-Cooperator Farmers } \\
\hline Components & $\begin{array}{l}\text { Mojokerto } \\
\text { (IDR/ha) }\end{array}$ & $\begin{array}{l}\text { Pasuruan } \\
\text { (IDR/ha) }\end{array}$ & Mojokerto (IDR/ha) & $\begin{array}{c}\text { Pasuruan } \\
\text { (IDR/ha) }\end{array}$ \\
\hline Input facilities cost (IDR/ha) & $1,983,952$ & $2,259,600$ & $1,798,711$ & $1,587,253$ \\
\hline Labor cost (IDR/ha) & $6,600,220$ & $5,132,052$ & $3,937,580$ & $4,332,461$ \\
\hline Total farming cost (IDR/ha) & $8,584,172$ & $7,391,652$ & $5,736,291$ & $5,919,714$ \\
\hline Grain yield $(\mathrm{kg} / \mathrm{ha})$ & 2240 & 2090 & 1766 & 1720 \\
\hline Grain selling price (IDR/kg) & 7200 & 7000 & 6400 & 6500 \\
\hline Revenue ( $\mathrm{Rp} / \mathrm{ha})$ & $16,128,000$ & $14,630,000$ & $11,302,400$ & $11,180,000$ \\
\hline Profit (Rp/ha) & $7,543,828$ & $7,238,348$ & $5,566,109$ & $5,260,286$ \\
\hline $\mathrm{B} / \mathrm{C}$ ratio * & 0.88 & 0.98 & 0.97 & 0.89 \\
\hline $\mathrm{R} / \mathrm{C}$ ratio ** & 1.88 & 1.98 & 1.97 & 1.89 \\
\hline Increase in $\mathrm{B} / \mathrm{C}$ ratio & 0.69 & 1.34 & & \\
\hline BEP production & 1.192 & 1.055 & 896.30 & 910.72 \\
\hline BEP price & 3832 & 3536 & 3248 & 3441 \\
\hline
\end{tabular}

* Profitable when $\mathrm{B} / \mathrm{C}$ ratio > bank interest rate $(0.02) ;{ }^{* *}$ Profitable when $\mathrm{R} / \mathrm{C}$ ratio $>1$.

Cooperator farmers' soybeans selling price is higher than for non-cooperator farmers. The selling price will affect the income earned by farmers. The selling price of soybean for cooperator farmers is IDR $7200 / \mathrm{kg}$ and IDR $7000 / \mathrm{kg}$ for Mojokerto and Pasuruan, respectively, and IDR $6400 / \mathrm{kg}$ and IDR $6500 / \mathrm{kg}$ for non-cooperator farmers in Mojokerto and Pasuruan. The lower selling price is due to the lower quality of soybeans. Revenue from cooperator farmers is IDR 16,128,000 and IDR 14,630,000 for Mojokerto and Pasuruan, respectively. Revenue for non-cooperator farmers was IDR 11,302,400 and IDR 180,000, respectively (Table 7). The selling price of soybeans is much lower than the price set by the government in 2017 of IDR 8500.

Farming profits depend on the amount of income and the cost of farming. The greater the revenue and the more efficient the farming costs, the greater the profit obtained. The profit obtained by cooperator farmers is greater than that of non-cooperator farmers. The profits of cooperator farmers were $35.53 \%$ and $9.52 \%$ greater than non-cooperator farmers in Mojokerto and Pasuruan, respectively. The profit for cooperator farmers in Mojokerto is IDR 7,543,828, and in Pasuruan IDR 7,238,348. Meanwhile, the profit for non-cooperator farmers in Mojokerto is IDR 5,566,109, and IDR 5,260,286 in Pasuruan.

The use of high-yielding soybean varieties has been proven to be financially beneficial and feasible. This is indicated by the value of the $R / C$ ratio $>1$, and the value of the $B / C$ ratio is much greater than the prevailing bank interest rate $(0.02)$. The $\mathrm{R} / \mathrm{C}$ ratio was 1.88 and 1.98, and the $\mathrm{B} / \mathrm{C}$ ratio was 0.88 and 0.98 in Mojokerto and Pasuruan, respectively (Table 5). When viewed from the aspect of investment feasibility in soybean farming using improved varieties, it can be indicated by the value of the increase in B/C ratio or MBCR of 0.69 and 1.34 for Mojokerto and Pasuruan, respectively (Table 8). This means that a one-unit investment in soybean farming in optimal land using improved varieties will earn a return that is 0.69 and 1.34 times more than the value invested in Mojokerto and Pasuruan, respectively. Both locations are profitable and feasible because they are far above the current bank interest rate $(>0.02)$; however, development in Pasuruan is more profitable. 
At the yield level of $2240 \mathrm{~kg} / \mathrm{ha}$ in Mojokerto and $2090 \mathrm{~kg} / \mathrm{ha}$ in Pasuruan, and the selling price of soybeans of Rp 7200/ kg in Mojokerto and IDR 7000/ kg in Pasuruan, BEP yields will be achieved at $1192 \mathrm{~kg} / \mathrm{ha}$ in Mojokerto and $1055 \mathrm{~kg} / \mathrm{ha}$ in Pasuruan. BEP prices were reached at IDR $3832 / \mathrm{kg}$ in Mojokerto and IDR 3536/kg in Pasuruan (Table 7).

Table 8. Competitiveness of soybean against its crop competitors in Mojokerto and Pasuruan Regencies, 2020.

\begin{tabular}{ccc}
\hline Regencies & Crop Competitors & Competitive Index \\
\hline Mojokerto & Maize & 0.86 \\
& Maize & 0.79 \\
Pasuruan & Mungbean & 0.93 \\
\hline
\end{tabular}

\subsection{Soybean Competitive Index}

In the same planting season as soybean, other crops such as maize and mungbean are also planted. These crops are alternative crops to soybeans and are known as competitor crops to soybeans. In an effort to earn the maximum benefit, each farmer has a different way of cultivating his/her plants so that in one stretch of land, several food plants can be cultivated. The competitor crops for soybeans and the magnitude of soybean competitiveness against their competitors are shown in Table 8.

The results showed that soybeans did not have a competitive edge with its competitors or had low competitiveness (Table 8). The competitive index value of soybeans with maize and mungbean is $<1$, which means that soybeans have a low competitive power against maize and mungbean.

\subsection{Soybean Competitive in Productivity Level}

To find out how much soybeans are able to compete with competing crops, it is necessary to calculate the amount of seed productivity expected. The amount of the expected level of productivity (expectation) of soybeans is based on the assumption of the current price level (Table 9).

Table 9. Soybean yield expectation to gain a competitive advantage in Mojokerto and Pasuruan Regencies, 2020.

\begin{tabular}{cccc}
\hline Regencies & Crop Competitors & $\begin{array}{c}\text { Soybean Seed Yield } \\
\text { Expectation } \\
\text { (kg/ha) }\end{array}$ & $\begin{array}{c}\text { Selling Price Level } \\
\text { (IDR/kg) }\end{array}$ \\
\hline Mojokerto & Maize & 5144 & 7200 \\
Pasuruan & Maize & 5217 & 7000 \\
& Mungbean & 3054 & - \\
\hline
\end{tabular}

The average seed yield (productivity) in Mojokerto is $2.24 \mathrm{t} /$ ha and the competitor crop for soybeans is maize. To be able to compete with maize, it is expected that soybean productivity should reach $5144 \mathrm{~kg} / \mathrm{ha}$ if the price of soybeans is at the current price of IDR $7200 / \mathrm{kg}$. In Pasuruan, the competing crops for soybeans are maize and mungbeans. To compete with maize, soybean productivity should reach $5217 \mathrm{~kg} / \mathrm{ha}$, and to compete with mungbean, soybean productivity should reach $3054 \mathrm{~kg} / \mathrm{ha}$ if the price of soybeans is IDR $7000 / \mathrm{kg}$. The low level of soybean competitiveness against competing maize crops is due to the inadequate access to external input (fertilizers, pesticides, and herbicides). Meanwhile, for maize farming, due to a better selling price and productivity, farmers applied maximum production input and cultivation facilities for better plant productivity. 


\subsection{Soybean Competitive in the Price Level}

When measured by the price level, so that soybeans can compete with competing crops, the expected price must be calculated with the assumption of the current level of production (Table 10).

Table 10. Soybean price expectations to gain a competitive advantage in Mojokerto and Pasuruan Regencies, 2020.

\begin{tabular}{cccc}
\hline Regencies & Crop Competitors & $\begin{array}{c}\text { Soybean Selling } \\
\text { Price Expectation } \\
\text { (IDR/ha) }\end{array}$ & $\begin{array}{c}\text { Soybean Seed Yield } \\
\text { Level } \\
\text { (kg/ha) }\end{array}$ \\
\hline Mojokerto & Maize & 14,428 & 2240 \\
Pasuruan & Maize & 14,893 & 2090 \\
\hline
\end{tabular}

The price of soybeans in Mojokerto is IDR $7200 / \mathrm{kg}$. Soybean price expectations when competing with maize reach IDR $14,428 / \mathrm{kg}$ and IDR $14,893 / \mathrm{kg}$ in Pasuruan. When competing with mungbean, the price of soybeans is IDR 10,193/ kg. By looking at the facts above, it is clear that soybean has very low competitiveness level.

\section{Discussion}

The financial analysis of soybean farming includes calculating the cost of production facilities, labor, post-harvest, and revenue [11]. The need for labor input for soybean farming varies considerably. In general, farmers use labor services within and outside the family. The largest labor costs are for planting and harvesting activities (Table 6). If labor management can be more efficient, it can save farming costs, which in turn can increase profits. This is inline with the research results of Elisabeth et al. [11], who found that the labor input costs take the largest portion of the soybean farm production costs, ranging from $50.3 \%$ to $72.5 \%$ either using the existing method of farmers or innovative technology. In addition to the use of a lot of labor outside the family, the wages were also quite expensive. However, with better management and efficiency, soybean farming will be more profitable and feasible to develop. Laksono and Adnan [12] stated that the more labor outside the family is used, the greater the real cost for labor wages that must be incurred by farmers. Therefore, farmers are expected to be able to effectively use labor that comes from within their own family in order to reduce the payment of labor wages.

Soybean farming has no competitiveness if the output is sold for consumption in the market to tofu and tempeh factories. However, if the soybean agribusiness policy to increase competitiveness results in a change in consumption patterns by marketing soybeans as a source of vegetable protein that is safe for health, but also as a source of functional food, then soybeans have potential a strategic value to increase national food security in a sustainable, healthy, and educative manner [13,14].

The competitive index value of $<1$ for soybeans shows that soybeans have a low competitive power against maize and mungbean. This shows that the economic value of maize farming is higher, the income is higher, and the efficiency of capital and resource utilization is also better. This is also supported by the research results of Krisdiana [15-17] that the competitive power of soybeans is low against maize. Although soybean productivity has increased from year to year, it has not yet been able to compete with maize. This condition can be overcome, among other factors, by increasing the productivity and the selling price of soybeans. Sarwono [18] stated that productivity has a positive and significant effect on soybean competitiveness in Indonesia. Likewise, the soybean competitiveness is lower than for mungbean. The results of the study are in line with those reported by Krisdiana $[15,16]$ that soybean farming in East Java has low competitive power against mungbean. Sukmaya [19] also revealed that soybean farming in Lamongan was not competitive and inefficient. 
Bowo et al. [20] revealed that soybean farming in Grobogan only has a comparative advantage, and is sensitive to changes in commodity prices, fertilizers, and changes in labor costs. This is in line with what was conveyed by Tri [21], who stated that the output price policy is an effective instrument to increase the profitability and competitiveness of soybean farming. Likewise, Zakaria et al. [22] also revealed that the obstacles to soybean farming include the absence of a guarantee of a proper price for soybeans and high quality seeds. Besides the price factor, which greatly affects the competitiveness of soybeans, Tarigan et al. [23] stated that an improved seed policy is the most improved policy for increasing the competitiveness of soybean compared to other policies. Social factors and financial aspects in the form of incentives play an important role in determining technology adoption [24-26]. The results of this study indicated that the $\mathrm{R} / \mathrm{C}$ ratio of soybean farming was 1.88 and 1.98 in Mojokerto and Pasuruan, respectively. These results were higher than those reported by Adri et al. [27], where the R/C was 1.13. The results of this study indicated that soybean farming in the research area was profitable and feasible. However, there is a need for farming incentives so that farmers are more enthusiastic about planting soybeans. The government's policy to increase the competitiveness and productivity of soybeans is to provide assistance to the farmers such as free seeds of superior varieties, soybean cultivation technology, and adequate pricing policies. A similar case occured in the North China plain (NCP) of China, where the soybean production was rather sensitive to the return gaps of soybean due to maize. Government policies such as appropriate subsidies are needed to restore the soybean area and soybean production as part of the national revitalization strategy of soybean production [28].

\section{Conclusions}

The findings of this study highlighted that the use of improved soybean varieties increased seed productivity compared to local soybean varieties both in Mojokerto and Pasuruan Regencies, East Java Province, Indonesia. The use of improved soybean varieties was considered financially feasible. Increasing farm profits is still possible with efficient management of farm costs. The competitiveness of soybeans is lower compared to maize and mungbean. Soybeans can compete with these two crops if the productivity and price are higher than the current conditions. Labor management should be more efficient to reduce soybean farming costs and increase profits.

Author Contributions: Conceptualization, R.K., F.R., A.H.; methodology, R.K., N.P., F.R, M.J.M.; investigation and analysis, R.K., N.P., I.S.; writing original draft preparation, R.K., A.H., M.J.M.; writing, review and editing, R.K., A.H., M.J.M.; supervision, A.H., M.J.M.; funding acquisition, M.J.M., F.R. All authors have read and agreed to the published version of the manuscript.

Funding: This study was funded in part from the research and development program provided by the PRN of the Ministry of Research and Technology/National Agency for Research and Technology of 2020/2021 Mandatory Innovative and Productive Research (Rispro), Educational Fund Management Institution (LPDP), Ministry of Finance of the Republic of Indonesia, with Contract Number 21/E1/PRN/2020.

Institutional Review Board Statement: Not applicable.

Informed Consent Statement: Informed consent was obtained from all subjects.

Data Availability Statement: Not applicable.

Acknowledgments: The authors would like to thank all the farmers who participated in this study. Our gratitude also goes to PRN of the Ministry of Research and Technology/National Agency for Research and Technology of Mandatory Innovative and Productive Research (Rispro), Educational Fund Management Institution (LPDP), and the Ministry of Finance of the Republic of Indonesia for their funding of this research.

Conflicts of Interest: The authors declare no conflict of interest. 


\section{References}

1. Harsono, A. Langkah Merengkuh Swasembada Kedelai. In Ragam Pemikiran Pengembangan Pertanian 2015-2016; Forum Komunikasi Profesor Riset; IAAARD Press (Badan Penelitian dan pengembangan Pertanian): Jakarta, Indonesia, 2017.

2. BPS (Badan Pusat Statistik). Statistik Indonesia 2019; Badan Pusat Statistik Indonesia: Jakarta, Indonesia, 2020. Available online: http:/ / www.bps.go.id (accessed on 23 January 2020).

3. Swastika, D.K.S. Beberapa Teknik Analisis Dalam Penelitian dan Pengkajian Teknologi Pertanian. J. Pengkaj. Dan Pengemb. Teknol. Pertan. 2004, 7, 90-103.

4. Santosa, P.; Suryadi, A.; Subagyo, H.; Latulung, B.V. Dampak teknologi sistem usaha pertanian padi terhadap peningkatan produksi dan pendapatan usahatani di Jawa Timur. J. Pengkaj. Dan Pengemb. Teknol. Pertan. 2005, 8, 15-28.

5. Saragih, B. Peranan Teknologi Tepat Guna dalam Pembangunan Sistem Agribisnis Kerakyatan dan Berkelanjutan; Seminar II Teknologi Tepat Guna: Bandung, Indonesia, 2000.

6. Rogers, E.M. Diffusion of Innovation, 5th ed.; The Free Press: A Division Of Simon \& Schuster, Inc.1230: New York, NY, USA, 2003.

7. Soekartawi. Analisis Usahatani; Universitas Indonesia Press: Jakarta, Indonesia, 1995.

8. Malian, H. Kebijakan Perdagangan Internasional Komoditas Pertanian Indonesia; Pusat Penelitian dan Pengembangan Sosial Ekonomi Pertanian: Bogor, Indonesia, 2004.

9. Siregar, M. Metoda Alternatif Penentuan Tingkat Hasil dan harga Kompetitif: Kasus Kedelai; Forum Penelitian Agroekonomi PPSE: Bogor, Indonesia, 1999.

10. dan Sumaryanto, S.M. Analisis Daya Saing Usahatani Kedelai di DAS Brantas. JAE 2003, 21, 50-71.

11. Elisabeth, D.A.A.; Harsono, A.; Sundari, T.; Nugrahaeni, N. Kajian Kelayakan Finansial Paket Teknologi Budidaya Kedelai Biodetas Pada Lahan Sawah Tadah Hujan. J. Pengkaj. Dan Pengemb. Teknol. Pertan. 2019, 22, 15-26.

12. Laksono, A. Kelayakan Usahata Tani Kedelai Dengan Pola Pengelolaan Tanaman Terpadu (PTT): StudiKasus Di Distrik Nimbokrang, Kabupaten Jayapura. Widyariset 2011, 14, 267-273.

13. Kata, A.; Osmet, O.; Analia, D. Analisis daya saing komoditas kedelai pada lahan kering di kabupaten Tebo. J. Agri Sains 2020, 4, 48-59. [CrossRef]

14. Zainuri, Z.; Paramu, H.; Krishnabudi, N.G. Local Soybean Agribusiness Policy Scenarios to Increase Competitiveness in the International Level. Int. J. Agric. Environ. Res. 2017, 3, 4064-4077.

15. Krisdiana, R. Dinamika Preferensi Petani dan Penyebaran Varietas Unggul Kedelai di Provinsi Nusa Tenggara Barat. Bul. Palawija 2012, 28, 93-101.

16. Krisdiana, R. Penyebaran Teknologi Dan Prospek Pengembangan Usahatani Kedelai Untuk Mendukung Kedaulatan Pangan Laporan Teknis Tahun Anggaran 2016; Balai Penelitian Tanaman Aneka Kacang dan Umbi: Malang, Indonesia, 2016.

17. Krisdiana, R. Penyebaran Teknologi Dan Prospek Pengembangan Usahatani Untuk Mendukung Kedaulatan Pangan: Laporan Teknis Tahun Anggaran 2017; Balai Penelitian Tanaman Aneka Kacang dan Umbi: Malang, Indonesia, 2017.

18. Sarwono, S.; Pratama, W. Analisis Daya Saing Kedelai Indonesia. JEJAK 2014, 7, 134-140.

19. Sukmaya, S.G.; Rachmina, D.; Saptana, S. Analisis daya saing dan dampak kebijakan pemerintah terhadap komoditas kedelai vs pengusahaan kedelai di kabupaten Lamongan, Jawa Timur. Forum Agribisnis 2017, 6, 21-52. Available online: http://journal.ipb. ac.id/index.php/fagb/article/view/17230 (accessed on 21 July 2021). [CrossRef]

20. Bowo, P.; Nurayati, A.; Imleesh, R. Analysis of Competitiveness and Government on Rice, Corn and Soybean Farming. JEJAK: J. Ekon. Dan Kebijak. 2016, 9, 159-169.

21. Tri, H. Impact of Government Policies on The Competitiveness of Soybean Farming System In Indonesia: Study in Bangsalsari District, East Java Province. J. Dev. Econ. 2010, 4, 52-62.

22. Zakaria, A.K.; Sejati, W.K.; Kustiari, R. The Analysis of Competitiveness of the soybean Commodity According to Agro the Ecosystem: The Case in Three Provinces in Indonesia. J. Agro Ekon. 2010, 28, 21-37. [CrossRef]

23. Tarigan, N.A.B.; Rahmaddiansyah, S. Analisis Faktor-Faktor yang Mempengaruhi Daya Saing Kedelai Indonesia. J. Ilm. Mhs. Pertan. 2020, 5, 130-142.

24. Sargent, K.; Hyland, P.; Sawang, S. Factor influencing the adoption of information technology in a construction business. Aust. J. Constr. Econ. Build. 2012, 12, 72-86.

25. Talukder, M. Factors affecting the adoption of technological innovation by individual employees: An Australian Study. ProcediaSoc. Behav. Sci. 2012, 40, 52-57. [CrossRef]

26. Roumani, Y.; Nwankpa, J.; Roumani, Y.F. The impact of incentives on the intention to try a new technology. Technol. Anal. Strateg. Manag. 2015, 27, 126-141. [CrossRef]

27. Adri, A.; Yarda, Y.; Suharyon, S. Analisis Ekonomi Dan Kelembagaan Usahatani Kedelai Desa Suo-Suo Kecamatan Sumay Kabupaten Tebo. J. Ilm. Ilmu Terap. Univ. Jambi JIITUJ 2020, 4, 34-42.

28. Zhang, Z.; Lu, C. Clustering Analysis of Soybean Production to Understand its Spatiotemporal Dynamics in the North China Plain. Sustainability 2020, 12, 6178. [CrossRef] 